\title{
УДК 159.937
}

Шепельова Марія Володимирівна, кандидат психологічних наук, молодший науковий співробітник лабораторії психології творчості Інституту психології імені Г. С. Костюка НАПН України

e-mail: m.shepelyova@gmail.com

\section{ОСОБИСТІСНІ ХАРАКТЕРИСТИКИ У ХУДОЖНІЙ ДІЯЛЬНОСТІ СТУДЕНТІВ}

\section{Анотація}

У статті подано результати емпіричного дослідження прояву художніх орієнтаиій («емоиійне навантаження художнього твору», «техніка зображення», «творчий підхід художника», «смислове навантаження твору»), особистісних характеристик («психічна неврівноваженість», яка є узагальненням оцінок за трьома шкалами нижнього рівня («невротизм», «психотизм», «депресія»); «асочиіальність» («совісність», «розгальмованість»); «інтроверсія» («загальна активність», «сором'язливість», «товариськість»); «сензитивність» («естетична вразливість», «жіночність»)), творчих характеристик та емпатії у студентів. Статистична обробка даних здійснювалася за допомогою визначення середніх значень, прочентних співвідночень, факторного аналізу для виявлення системоутворювального фактору та множинного лінійного регресійного аналізу для визначення впливу особистісних характеристик на художні орієнтації студентів у сприйманні творів живопису. Виявлено, щчо системоутворювальним фактором художніх орієнтащій студентів у сприйманні живопису $є$ орієнтація на емоџійне навантаження твору. Встановлено, щуо на орієнтацію студентів на емоџійне навантаження у сприйманні творів живопису впливають такі показники: раціональний канал емпатії, ідентифікаиія в емпатії, загальна активність, совісність, схильність до ризику, жіночність, інтуїтивний канал емпатії, установки, що сприяють або перешкоджають емпатії, розгальмованість, емоційний канал емпатії, проникаюча здатність в емпатії, сором'язливість. Одержані 
результати дають можливість побови психологічного портрету студентів, схильних до орієнтації на емоџійне навантаження твору, а також показують які саме особистісні характеристики виступають блокіраторами у сприйманні живопису.

Ключові слова: художність, художні орієнтаиї̈ у сприйманні творів живопису, особистісні характеристики, емпатія, студенти.

Шепелёва Мария Владимировна, кандидат психологических наук, младший научный сотрудник лаборатории психологии творчества Института психологии имени Г. С. Костюка НАПН Украины

\section{ЛИЧНОСТНЫЕ ХАРАКТЕРИСТИКИ В ХУДОЖЕСТВЕННОЙ ДЕЯТЕЛЬНОСТИ СТУДЕНТОВ}

\section{Аннотация}

В статье поданы результаты эмпирического исследования проявления художественных ориентаций («эмоциональная нагрузка художественного произведения», «техника изображения», «творческий подход художника», «смысловая нагрузка художественного произведения»), личностных характеристик («психическая неуравновешенность», которая есть обобщением оценок по трем шкалам нижнего уровня («невротизм», «психотизм», «депрессия»); «асочиальность» («совестливость», «расторможенность»); «интроверсия» («общая активность», «робость», «общиттельность»); «сензитивность» («эстетическая впечатлительность», «женственность»)), творческих характеристик и эмпатии у студентов. Статистическая обработка данных проводилась с помощью определения средних занчений, процентных соотномений, факторного анализа для выявления системообразующего фактора и множественного линейного регрессионного анализа для определения влияния личностных характеристик на художественные ориентации студентов в восприятии живописи. Выявлено, что системообразующим фактором художественных ориентаций студентов в восприятии живописи есть ориентация на эмоциональную 
нагрузку произведения. Установлено, что на ориентациию студентов на эмоциональную нагрузку произведения влияют такие показатели: рациональныцй канал эмпатии, идентификаџия в эмпатии, общзая активность, совестливость, склонность к риску, женственность, интуитивный канал эмпатии, установки, которые способствуют или препятствуют эмпатии, расторможенность, эмоциональный канал эмпатии, проникающая способность в эмпатии, робость. Полученнье результаты дают возможность построения психологического портрета студентов, склонных $к$ ориентацуии на эмоциональную нагрузку произведения, а также показывают какие именно личностные характеристики выступают блокираторами в восприятии живописи.

Ключевые слова: художественность, художественные ориентации в восприятии произведений живописи, личностные характеристики, эмпатия, cmуденты.

Shepelova Mariia Volodymyrivna, candidate of psychological sciences, junior researcher in the Psychology of Creativity Department of G. S. Kostiuk Institute of Psychology of NAES of Ukraine

\section{THE PERSONALITY CHARACTERISTICS IN STUDENTS'ARTISTIC}

\section{ACTIVITY}

\section{Summary}

Article presents the results of empirical research of artistic orientations ("the emotional content", "the technique of depiction", "the artist's creative approach" and "the semantic content"), personality characteristics ("mental imbalance”, which is a generalization of grades in three lower-level scales ("neuroticism”, "psychoticism", "depression”); "Asociality", ("conscientiousness", “disinhibition”); "Introversion” ("general activity”, "modesty", "sociability”); "Sensitivity" ("aesthetic susceptibility", “femininity")), creativity and empathy displays among students. Quantitative data processing was carried out by the means of the average values defining, 
percentage ratios, and factor analysis for the system-forming factor defining, and multiple linear regression analysis for the following defining of the influence of personality characteristics on students' artistic orientations in paintings' perception. It is revealed that a system-forming factor in the students' artistic orientations in painting perception is an orientation on emotional content of artistic work. It is found that following twelve indicators (rational channel of empathy, identification in empathy, general activity, conscientiousness, risk, femininity, intuitive channel of empathy, attitudes, promoting or preventing empathy, disinhibition, emotional channel of empathy, penetrating ability in empathy, modesty) influence on students' orientation on emotional content of artistic work. The results give us a possibility to create a psychological portrait of students, oriented on emotional content of artistic work, and also show which of the characteristics are blocking in painting perception.

Key words: artistry, artistic orientations in painting perception, personality characteristics, creativity, empathy, students.

Problem statement. The artistry is an integrative attribute of an art, which is a criterion of a work's confession to an art and manifests itself only in the work's and perceiver's interaction. The basis for works of painting is reality, interpreted and embodied by the artist in a work of art in a picturesque form. The artistry as an integrative attribute of an art includes the following characteristics [4]:

1) cognitive capacity;

2) assessments system (value-orientation component);

3) communicative characteristics (the sign and symbolic system's clarity, accessibility);

4) technical characteristics;

5) aesthetic qualities (the work's ability to cause aesthetic experiences).

All of the above characteristics are considered as different sides of one whole. The work of art contains the above characteristics in their different 
proportions [4]. Both in the work of art and in its real impact on a person one can distinguish different aspects (for example - cognitive, emotional). But at the same time, the main feature of an artistic work is integrity, the violation of which leads to the artistic image's disintegration.

Namely because the painting's artistry is determined by unique combination of these components, each painting creates a special impression on the perceiver, which is also integrative, that reflects a combination of these components together.

The purpose of this article is to define the influence of students' personality characteristics on the artistic orientations in paintings' perception.

Initial premises. We consider artistic activity in a broad sense: both as an independent aesthetic creativity in the field of art and literature [4] (i.e., the process of creativity itself), and as a process of perceiving products of aesthetic creativity.

The artistic orientations in paintings' perception consist of four components:

1) emotional filling of artistic work;

2) technique of the depiction (application by the artist of specific painting means and techniques that are more relevant to the formal characteristics of the work);

3) the artist's creative approach;

4) semantic filling of the work of art.

Each of these components is displayed in the painting with the following indicators.

Emotional filling of artistic work:

- the mood that the painting expresses (the mood in the painting is expressed through the nature of the lines, strokes, colours, contrasts and causes the emotional response of the viewer, which further creates an emotional background of perception);

- the ability of the painting to cause the perceivers' amazement, experience, interest;

- the ability of the painting to cause perceivers' memories;

- creating by a picture of the involvement effect on the viewer (feeling like 
a participant of events).

Technique of the depiction:

- the external attractiveness of the painting;

- composition integrity;

- pleasant, harmonious colour gamma, colour contrasts' presence;

- the artist's ability to depict objects and phenomena realistically, to display the dynamics and volume on the plane of the picture.

The artist's creative approach (application by the artist of specific painting means and techniques that are more relevant to the content characteristics of the work):

- unusual, original plot;

- the depicted objects' unusual combination;

- integration of the opposite in sense objects/phenomena in the painting;

- the presence of the artists' unique style of the depiction.

Semantic filling of the work of art:

- the artistic image's polysemanticism (the possibility of ambiguous interpretation of the content laid down in the work by the artist);

- disclosure of an abstract concept or idea by the artistic image;

- the plot supposes the presence of prehistory and events' development in the future;

- the presence in the picture of a deep thought, an idea, going beyond the directly depicted in the picture.

All of the foregoing became the basis for planning, conducting and analyzing the results of an empirical study of personality characteristics influence on students' artistic orientations in paintings perception.

The basic material statement. Basing on the defined painting's artistic features and displays of the artist's use of perceptive-mental strategies of analogizing, combining, reconstructing and demonstrating of the artist's personality in the work of art [10], we have developed a questionnaire "Paintings' perception artistic orientations", which allows to estimate the dominant artistic orientations of 
the students in the process of paintings' perceiving by such indicators: "emotional filling of artistic work", "technique of the depiction", "the artist's creative approach" and "semantic filling of the work of art".

Empathy level in the subjects is defined using the questionnaire "The Diagnostics of the empathic abilities level" V. V. Boyko [5]. It allows to esteem the general level of empathy and its separate components: rational (characterizes the orientation of attention, perception and thinking on the other person's essence its state, problems, behaviour), emotional (ability to take the same emotional wave with the surrounding, to empathize, sympathize) and intuitive (ability to see the partners' behaviour, to act in the conditions of the lack of actual information about them, leaning on experience) empathy channels, attitudes, promoting or preventing empathy (the empathy effectiveness falls if a person tries to avoid personal contacts, considers it to be inappropriate to show the interest to the others, convinced himself to be calm towards the experiences and problems of others), penetrating ability in empathy (an important communicative attribute of personality, which allows to create the atmosphere of openness, trust, sincerity.

To study the personality characteristics of the subjects, we used a multiplefactor personality questionnaire "Psychodiagnostic test" (PDT) by V. M. Melnikov and L. T. Yampolsky $[6,7]$. The questionnaire allows to distinguish ten lowerlevel scales corresponding to personality factors: neuroticism (estimates the level of subjects' neurotization), psychoticism (estimates the degree of psychological adequacy of the individual), depression (estimates the depth of subjective experiences that occur when the dominant background mood is reduced), conscientiousness (shows the degree of social norms' and ethical requirements' respect), disinhibition (estimates the level of restraint, socialization of behaviour), general activity (estimates the level of activity, energy of the individual), modesty (estimates shyness, constraint in the interpersonal relationships), sociability (aimed at estimation of the width and intensity of communication), aesthetic susceptibility (estimates sensitivity to aesthetic and artistic values), femininity (estimates the identification degree of the subject with a female role attributed by culture and 
society); and the four upper-level scales, which are a generalization of the previous scales: "mental imbalance", which is a generalization of grades in three lower-level scales ("neuroticism", "psychoticism", "depression") and is intended for an integral assessment of the psychological stability of the individual; "Asociality", which is a generalization of grades in two lower-level scales ("conscientiousness", "disinhibition") and is intended for an integral estimation of the social adaptability of the individual; "Introversion", which is a generalization of grades on three lower-level scales ("general activity", "modesty", "sociability") and is intended for an integral estimation of the personality's sociability; "Sensitivity", which is a synthesis of grades for two lower-level scales ("aesthetic susceptibility", "femininity") and is intended for an emotional experiences' delicacy integral assessment $[6,7]$.

For the students' creative characteristics defining we used the Williams' questionnaire of personality creative characteristics, modified by E.E. Tunik [8], with the help of which we defined such features of students' creativity: risk, complexity, curiosity and imagination. Risk displays in such qualities: constructive critics' perception, possibility of filature acceptance; trying to put forward hypotheses, guesses; to act in non-structured conditions; to protect own aims. Complexity displays in finding of several alternatives; seeing differences in what we have and what we may have; intention to order not ordered things; to solve difficult tasks, to have doubts in only one right solving. The displays of curiosity are playing with ideas, finding of way out in ambiguous situations, interest to riddles, puzzles; thoughts about hidden meaning of something. Imagination displays in ability for visualization, trust to intuition [8].

The empirical research sample contains 37 (58\%) Psychology students, 13 (20\%) Technical students of the I-VI years of study, 16-25 years old; and others $14(22 \%)$ 25-44 years old. General sample size is 64 persons. Among them are 16 men (25\%) and 48 women (75\%). The research was carried remotely with the use of the Google-form service. Participants were motivated by the opportunity of getting individual cards with their research results. 
Quantitative data processing was carried out by the means of the average values defining, percentage ratios, factor analysis for the system-forming factor defining, and multiple linear regression analysis, for defining of the influence of students' personality characteristics on artistic orientations in paintings' perception.

The research results of the students' artistic orientations' displays in the process of paintings' perception by the indicators "emotional filling of artistic work", "technique of the depiction", "the artist's creative approach" and "semantic filling of the work of art", their personality characteristics and empathy are presented in Table 1.

Table 1.

The Average Values of the Students' Artistic Orientations in Paintings'

Perception, their Creative Orientations, Personality Characteristics,

Creativity and Empathy

\begin{tabular}{|c|c|}
\hline \multicolumn{2}{|c|}{ Artistic Orientations } \\
\hline Indicators & Average Values (\%) \\
\hline Emotional filling of artistic work & 74 \\
\hline Technique of the depiction & 69 \\
\hline The artist's creative approach & 69 \\
\hline Semantic filling of artistic work & 71 \\
\hline \multicolumn{2}{|c|}{ Personality Characteristics } \\
\hline Indicators & Average Values (points) \\
\hline Mental imbalance & 6.1 \\
\hline Neuroticism & 6.6 \\
\hline Psychoticism & 5.1 \\
\hline Depression & 7.0 \\
\hline Asociality & 4.6 \\
\hline Conscientiousness & 6.0 \\
\hline Disinhibition & 5.6 \\
\hline Introversion & 5.8 \\
\hline General activity & 5.1 \\
\hline
\end{tabular}




\begin{tabular}{|c|c|}
\hline Modesty & 5.2 \\
\hline Sociability & 6.1 \\
\hline Sensitivity & 5.8 \\
\hline Aesthetic sensibility & 6.0 \\
\hline Femininity & 6.9 \\
\hline \multicolumn{2}{|c|}{ Creativity } \\
\hline Indicators & Average Values (points) \\
\hline Creativity (general) & 5.5 \\
\hline Risk & 5.1 \\
\hline Complexity imagination & 5.8 \\
\hline Curiosity & 5.6 \\
\hline Imagination & 5.5 \\
\hline \multicolumn{2}{|c|}{} \\
\hline
\end{tabular}

Further we used factor analysis for the defining of system-forming factor among the researched indicators, which allows with the factor loadings' calculation to distinguish one or several indicators in the system of factors, optimally connected with the other indicators [2]. The system-forming is a factor, which defines the integration of the components into a system [3]. In other words, with the help of these calculations we define such of studied indicators, which is determining in the integration of all studied motivational sphere's indicators into a system.

When it is required to follow the tendency, to construct the sequence, the hierarchy of system-forming factors, which accompanies the research phenomenon, is calculated by the means of step-by-step exclusion of systemforming factors from the system of factor loadings' calculation.

Factor loadings for the artistic orientations in the paintings' perception (emotional filling of artistic work, technique of the depiction, the artist's creative approach and semantic filling of the work of art) are presented in Table 2.

Table 2. 
The Students' Artistic Orientations Displays' Factor Loadings Hierarchy

\begin{tabular}{|c|c|}
\hline$\#$ & Factor Loadings Hierarchy (with factor loadings in brackets) \\
\hline 1 & Emotional filling of artistic work $(0.52)$ \\
\hline 2 & The artist's creative approach $(0.44)$ \\
\hline 3 & Semantic filling of artistic work $(0.42)$ \\
\hline 4 & Technique of the depiction $(0.34)$ \\
\hline
\end{tabular}

By the studied artistic orientations' displays in the paintings' perception (by the indicators "emotional filling of artistic work", "technique of the depiction", "the artist's creative approach" and "semantic filling of the work of art") empiric research results, average values analysis showed the following tendency: the first goes emotional filling of artistic work, the second - semantic filling of the work of art, the third goes technique of the depiction and the artist's creative approach.

Next, let's consider the results of artistic orientations' displays in the paintings' perception factor loadings' calculations (see Table 2) in students: the emotional filling of artistic work (0.52); semantic filling of the work of art (0.50); the artist's creative approach (0.48); technique of the depiction (0.42). Thus, the system-forming among the artistic orientations' displays in the paintings' in students is the emotional filling of artistic work.

The results of factor loadings calculating after the exclusion of the main system-forming factor are following: the artist's creative approach (0.44); semantic filling of the work of art (0.42); technique of the depiction (0.34). Thus, the second most significant is the artist's creative approach, the semantic filling of the work of art and the technique of the depiction have the least value among the artistic orientations' displays in the paintings' perception by students.

For the defining of personality characteristics of the students' artistic orientations in paintings' perception we used the method of multiple linear regression analysis. This method consists in the regression equation construction, which describes the influence of the group of factors on the resulting indicator. In the most simple (pair) variant regression equation has following appearance: 


$$
y=a+b x .
$$

Indicator $a-$ is a free term of equation, expressing the influence of unaccounted in the model factors on the variable $y$, indicator $b$-is a regression coefficient, shows on which quantity at the average value of variable $y$ will change with the corresponding change of variable $x$ per unit of measure. Therefore, regression coefficient shows the impact of variable $x$ into the variable $y$.

The multiple regression equation allows estimating the dependence of the resulting indicator of several factors and has following appearance:

$$
y=a+b_{1} x_{1}+b_{1} x_{1}+\ldots
$$

The parameters of model estimation are also the multiple correlation coefficient $\mathrm{R}$, which is the measure of linear multiple correlation of several factors with the resulting variable at once, and the determination coefficient $\mathrm{R}^{2}$, showing what part of dependant variable's dispersion is caused by the collection of independent variables [1].

This method application allows defining what students' personality characteristics influence on their system-forming artistic orientation in paintings' perception - emotional filling of artistic work. The sign «+» in the equation have personality characteristics, which raise the students' orientation on the emotional filling of artistic work. And, on the contrary, the sign «-» in the equation have personality characteristics, which lower the students' orientation on the emotional filling of artistic work in the process of paintings' perception. Moreover, if using standardized indicators in the calculations (as we did), the multiple regression coefficient shows the correlation of the factor with the dependent variable in consideration of its' correlation with other factors. That is the weaker correlation of the factor with other factors and the stronger it is with the resulting indicator, the stronger is regression coefficient. The results of multiple linear regression analysis are presented in Table 3.

Table 3.

The influence of students' personality characteristics on the artistic orientations in paintings' perception (by the results of multiple linear 
regression calculations)

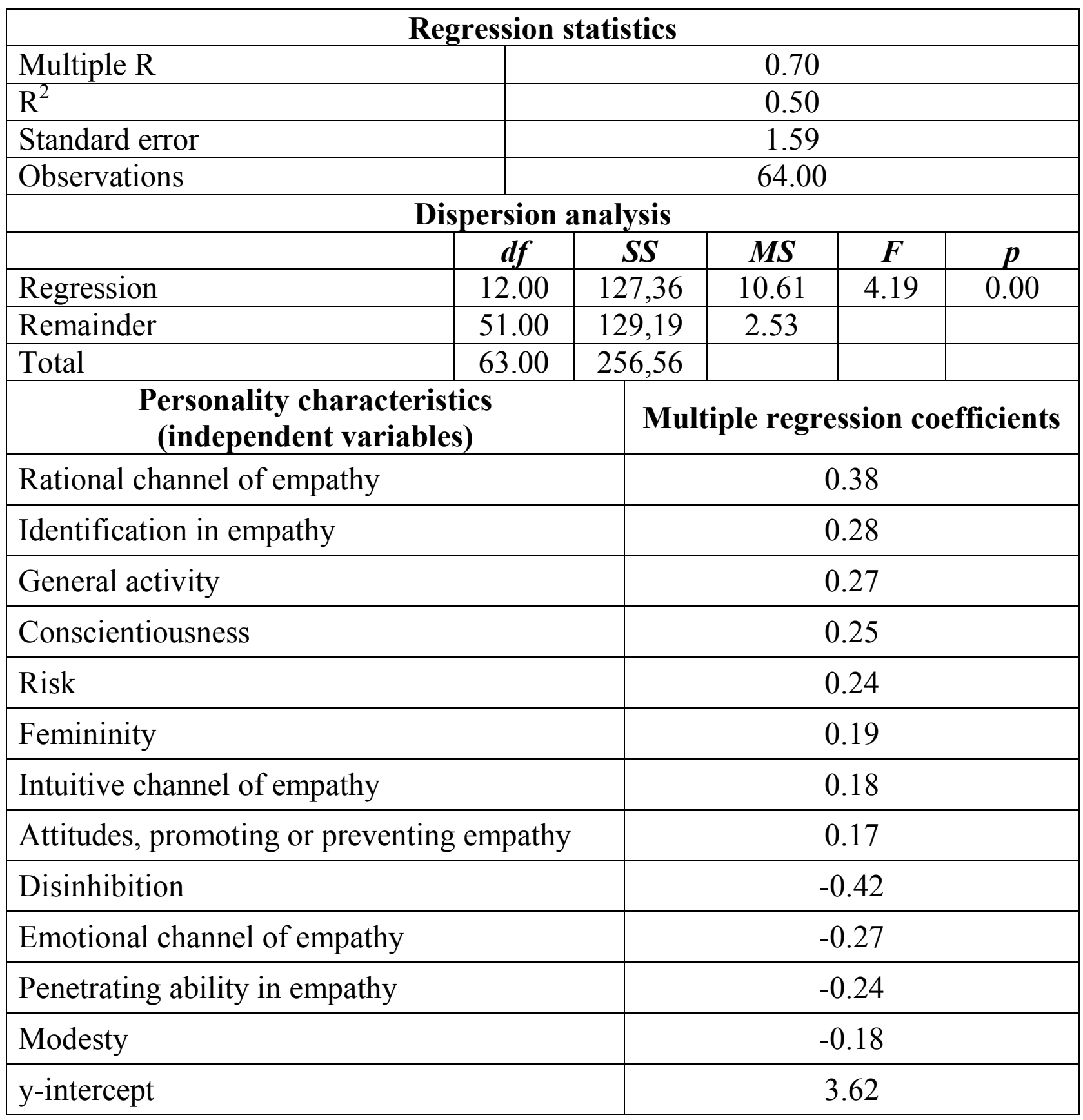

The students' artistic orientations in paintings' perception by the results of multiple linear regression calculations are influenced by following twelve personality characteristics: rational channel of empathy, identification in empathy, general activity, conscientiousness, risk, femininity, intuitive channel of empathy, attitudes, promoting or preventing empathy, disinhibition, emotional channel of empathy, penetrating ability in empathy, modesty.

Methodological significance. The research results give us a possibility to create a psychological portrait of students, oriented on emotional content of artistic work, and also show which the characteristics are blocking in painting perception. 
Conclusions. In the article, according to the results of empirical research, the tendencies of artistic orientations ("the emotional content", "the technique of depiction", "the artist's creative approach" and "the semantic content"), personality characteristics and empathy displays among students are revealed.

Basing on the factor weights calculation, it is revealed that a system-forming factor in the students' artistic orientations in painting perception is an orientation on emotional content of artistic work. The second in importance is the artist's creative approach, the semantic content of the work and the technique of depiction are of the least importance among the artistic orientations displays in the perception of artistic works.

With the use of multiple linear regression analysis, it was found that the orientation of students on the emotional content of the work is positively influenced by the following indicators: rational channel of empathy, identification in empathy, general activity, conscientiousness, risk inclination, femininity, intuitive channel of empathy, attitudes that contribute to or impede empathy. The following factors have a negative impact: disinhibition, emotional channel of empathy, penetrating ability in empathy, modesty.

Further research perspectives. Built with the help of regression analyses multidimensional model is not exhaustive and provides further defining of nonlinear influence of personality characteristics and their interaction on the students' artistic orientations in paintings' perception.

\section{Список використаних джерел}

1. Бурлачук Л. Ф. Словарь-справочник по психодиагностике / Л. Ф. Бурлачук, С. М. Морозов ; отв. ред. Крымский С. Б. - К. : Наук. думка, 1989. - $200 \mathrm{c}$.

2. Бешелев С. Д. Математико-статистические методы экспертных оценок / С. Д. Бешелев, Ф. Г. Гурвич. - М.: Статистика, 1980. - 263 с.

3. Бродовська В. Й. Тлумачний російсько-український словник психологічних термінів / В. Й. Бродовська, В. О. Грушевський, І. П. Патрик. К. : Професіонал, 2007. - 512 с. 
4. Новиков А. М. Методология

/ А. М. Новиков. - М. : Эговес, 2008. - 72 с.

5. Бойко В В. Энергия эмоций в общении: взгляд на себя и других / В. В. Бойко. - М., 1996.

6. Мельников В. М. Введение в экспериментальную психологию личности / В. М. Мельников, Л. Т. Ямпольский. - М. : Просвещение, 1985. $319 \mathrm{c}$.

7. Психодиагностический тест (ПДТ) В. Мельникова, Л. Ямпольского / Практикум по психодиагностике личности // Ред. Н. К. Ракович. - Минск, 2002. - C.75-91.

8. Туник Е. Е. Модифицированные креативные тесты Вильямса / Е. Е. Туник. - СПб. : Речь, 2003. - 96 с.

9. Шепельова М. В. Методичні матеріали для діагностики та розвитку здатності студентів до художньої діяльності [Електронний ресурс] / М.В.Шепельова // Стимулювання творчого сприймання інформації : методичні рекомендації / В. О. Моляко, Ю. А. Гулько, Н. А. Ваганова [та ін.]; за ред. В. О. Моляко. - К., 2018. - С. 47-53. - Режим доступу: http://lib.iitta.gov.ua/712862/

10. Шепельова М. В. Прояви перцептивно-мисленнєвих стратегій у художній діяльності студентів [Електронний ресурс] / М. В. Шепельова // Перцептивно-мисленнєві стратегії творчого конструювання інформаційних систем у навчальній та трудовій діяльності : монографія / В. О. Моляко, Ю. А. Гулько, Н. А. Ваганова [та ін.] ; за ред. В. О. Моляко. - К., 2018. - С. 106-123. - Режим доступу: http://lib.iitta.gov.ua/712092/

\section{References transliterated}

1. Burlachuk L. F. Slovar-spravochnik po psikhodiagnostike / L. F. Burlachuk, S. M. Morozov ; otv. red. Krymskii S. B. - K. : Nauk. dumka, 1989. - $200 \mathrm{~s}$.

2. Beshelev S. D. Matematiko-statisticheskie metody ekspertnykh otcenok / 
S. D. Beshelev, F. G. Gurvich. - M.: Statistika, 1980. - 263 s.

3. Brodovska V. Y. Tlumachnyi rosiisko-ukrainskyi slovnyk psykholohichnykh terminiv / V. Y. Brodovska, V. O. Hrushevskyi, I. P. Patryk. - K. : Profesional, 2007. - $512 \mathrm{~s}$.

4. Novikov A. M. Metodologiia khudozhestvennoi deiatelnosti / A. M. Novikov. - M. : Egoves, 2008. - 72 s.

5. Boiko V V. Energiia emotcii v obshchenii: vzgliad na sebia i drugikh / V. V. Boiko. - M., 1996.

6. Melnikov V. M. Vvedenie v eksperimentalnuiu psikhologiiu lichnosti / V. M. Melnikov, L. T. Iampolskii. - M. : Prosveshchenie, 1985. - 319 s.

7. Psikhodiagnosticheskii test (PDT) V. Melnikova, L. Iampolskogo / Praktikum po psikhodiagnostike lichnosti // Red. N. K. Rakovich. - Minsk, 2002.S.75-91.

8. Tunik E. E. Modifitcirovannye kreativnye testy Viliamsa / E. E. Tunik. $\mathrm{SPb}$. : Rech, 2003. $-96 \mathrm{~s}$.

9. Shepelova M. V. Metodychni materialy dlia diahnostyky ta rozvytku zdatnosti studentiv do khudozhnoi diialnosti [Elektronnyi resurs] / M. V. Shepelova // Stymuliuvannia tvorchoho spryimannia informatsii : metodychni rekomendatsii / V. O. Moliako, Yu. A. Hulko, N. A. Vahanova [ta in.]; za red. V. O. Moliako. - K., 2018. - S. 47-53. - Rezhym dostupu: http://lib.iitta.gov.ua/712862/

10. Shepelova M. V. Proiavy pertseptyvno-myslennievykh stratehii $u$ khudozhnii diialnosti studentiv [Elektronnyi resurs] / M. V. Shepelova // Pertseptyvno-myslennievi stratehii tvorchoho konstruiuvannia informatsiinykh system $\mathrm{u}$ navchalnii ta trudovii diialnosti : monohrafiia / V. O. Moliako, Yu. A. Hulko, N. A. Vahanova [ta in.] ; za red. V. O. Moliako. - K., 2018. - S. 106123. - Rezhym dostupu: http://lib.iitta.gov.ua/712092/ 